Journal of Finance and Accounting

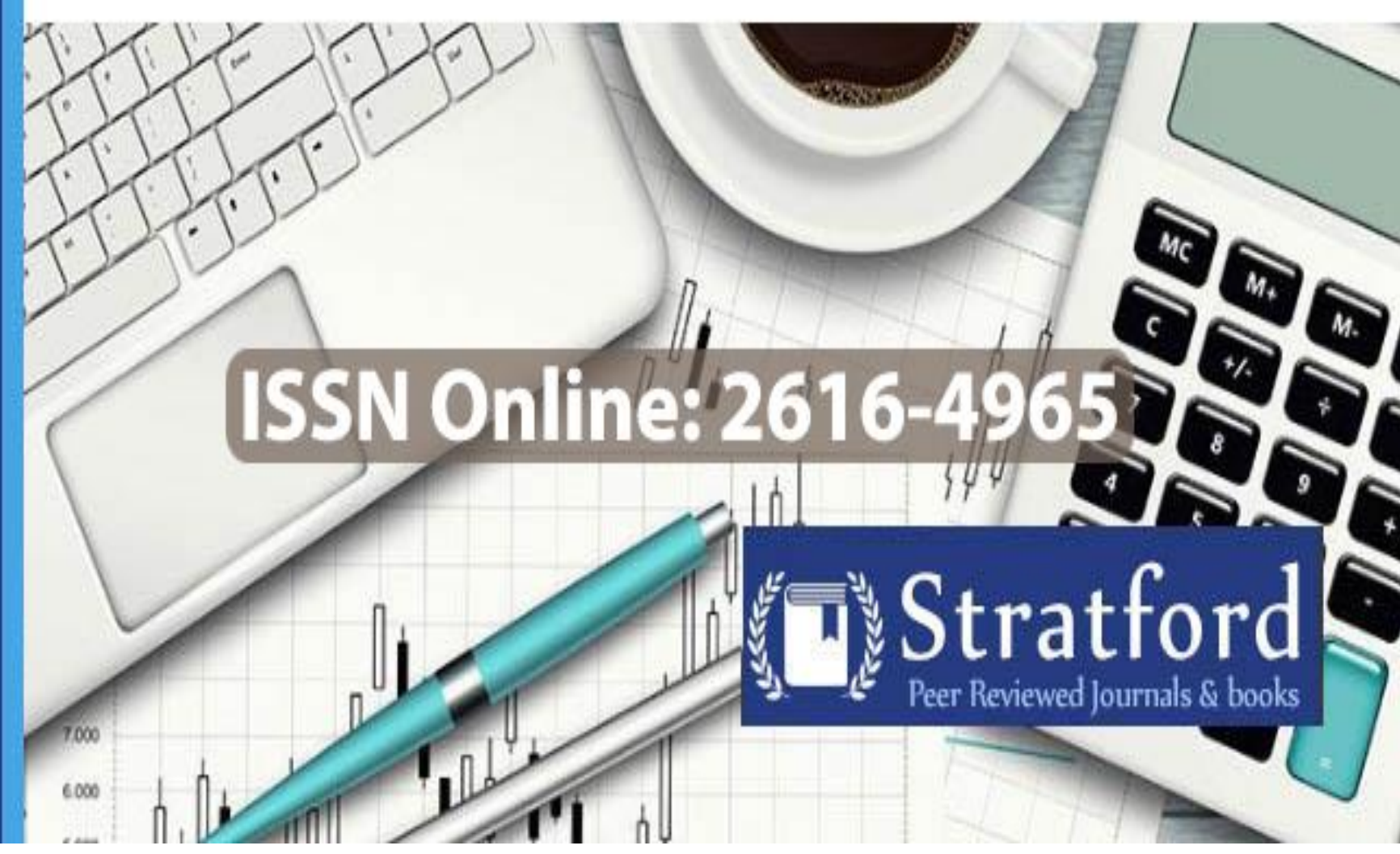

Capital Market Development and Internal Borrowing in Latin America Countries

Martina Olivia \& Catalina Alma

ISSN NO: 2616 - 4965 


\title{
Capital Market Development and Internal Borrowing in Latin America Countries
}

\author{
Martina Olivia, University of Argentina \\ Dr. Catalina Alma, University of Argentina
}

How to cite this article: Olivia M. \& Alma C. (2021). Capital Market Development and Internal Borrowing in Latin America Countries. Journal of Finance and Accounting. Vol 5(4) pp. 12-22. https://doi.org/10.53819/81018102t2019

\begin{abstract}
In many developing countries, governments have given much attention to domestic debt compared to external indebtedness. Despite the fact that domestic borrowing has many advantages; it also has negative impacts especially when it goes beyond a sustainable amount. Domestic debt affects a country's inflation rates, interest rates among many other factors. Through this study of how various concepts are affected by domestic borrowing, various governments will clearly understand the effects of domestic borrowing on their capital market development and align their domestic debts from the capital market institutions that will finally promote the development of the capital markets. The study used a descriptive research, which involved the measurement, classification, analysis, This study adopted the descriptive study design. The study concluded that there is a positive relationship between high domestic public debt and capital market development, an increase in domestic debt causes the capital market development to decrease. When a country borrows more domestic, debt and less external debt it promotes capital markets development in the long run. The regression model used in the study was statistically significant in explaining the effect of domestic public debt on capital markets development in South America Countries. The study further concluded that inflation rate has a negative impact on financial market development this implies that inflation had a negative impact on capital markets development. It also conclude that an increase in interest rate impact positively the capital markets development. The study recommends on continued deepening of the capital markets to lengthen further the maturity profile of domestic debt and diversification of the investor base. The study further recommends on continued implementation of policies to support macroeconomic stability and faster economic growth. This includes restructuring public debt towards external borrowing which is comparably cheaper than domestic debt, and rationalization of recurrent expenditures to contain the widening deficit in the primary balance would be necessary in the medium-term to ensure that public debt remains on a sustainable path to allow for capital markets development.
\end{abstract}

Keywords: Capital Market Development, Domestic Borrowing, \& Latin America Countries. 


\subsection{Introduction}

Government requires many resources when it comes to public expenditure. When taxes are not enough to provide the bulk of revenue, governments engage in public borrowing that bridges the gap between the receipt and expenditure (Coşkun, Seven, Ertuğrul \& Ulussever, 2017). Public debt whether international and domestic is one of the macroeconomic indicators of a country's economic growth. Through the public debt position, various international markets are in a position to form a country's image. As International Monetary Fund (2010) argues in its work; reasonable levels of borrowing may enhance a country's economic growth. As long as the country ensures that the borrowed funds are used for productive investments, domestic debt is a good source of country's capital. Brauninger (2013) defines domestic debt as the debt that the government owes to the holders of the government securities. This debt is divided into two that is the debt receipts and the debt disbursals. According to a study that was conducted by Mingo, Junkunc and Morales (2018), such economic development comes through capital accumulation and productivity growth that happens courtesy of the domestic and international public debt. Despite the many pros of domestic debt to developing governments, such debt also has severe cons on the economy especially when not well balanced with the anticipated economic growth (Abbas \& Christensen, 2017).

Public debt is basically debt owed by a government to the holders of government securities. Domestic borrowing involves borrowing of government securities such as T-bills, T-bonds and infrastructure bonds thus internal borrowing. Public debt could also be external acquired from the international markets. According to Garretsen, Lensink, Sterken (2014), domestic debt is borrowed in local currency and is shielded from foreign exchange risks while external debt is borrowed in foreign currency. Public debts are meant for development of government projects, meet budget deficits and in any case of adverse situations such as war and natural disasters: be able to finance such expenses. A capital market is a financial market where debt and equity securities are bought or sold. These markets channels wealth of savers to long term users who will put the resources into productive use. Capital market development is very key in contributing to economic growth of a country which helps in bringing together savings that will be used in a country's development. Stable capital markets are a good indicator of continued economic growth and a mitigate of financial risks. The development of such strong and stable markets requires regulatory frameworks to ensure continued capital market supervision and development.

There is a correlation between the dependent and the independent variables in this study. For example, it is hypnotized that the performance of these capital markets is affected by the independent variables shift. For example, when the domestic public debts get high, it influences the factors that cause distress of the financial market performance. According to (Avendano, Melguizo \& Miner, 2017) reasonable domestic borrowing may enhance a country's economic growth that happens through capital accumulation and productivity growth. For example, countries that are at early stages of development tend to have small stocks of capital that it becomes hard to finance their projects. When such a country borrows money and uses it for productive investment, it does not suffer from macroeconomic instability and sizable adverse shocks among others.

\subsection{Statement of the Problem}

The main focus of this study is getting to understand the correlation between domestic public debt and South America Countries capital market development. In many ways, the capital market is symmetrical to the country's public debt. In many developing countries, governments have given 
much attention to domestic debt compared to external indebtedness. According to a study that was conducted by Akram (2010), issuing of the domestic debt involves complex assessments that involve costs and benefits. Management of the public debt leads to economic growth and stability since it requires low borrowing costs and a reduced financial risk exposure.

When it comes to the development of a market, instruments of debt becomes important. When a country takes large amounts of domestic debt, debt servicing costs largely increase that negatively affects the capital market development. In South America Countries, countries have been performing differently when it comes to public debt. In South America Countries, the policymakers have been increasing domestic borrowing that is affecting the economic growth. In Chile, the government uses domestic borrowing to finance various infrastructure projects. For many years, governments' domestic debt has been affecting many countries' capital market development. However, many countries cannot survive without the use of such debts. In various countries in the world, high public debt has adversely been affecting various countries as Brauninger (2013) argues in his work. Because of the lack of adequate information regarding the topic, many countries are making mistakes that could have been easily eliminated. The lack of adequate information regarding this topic makes this topic worth studying. In many ways, a wellmanaged public domestic debt leads to a great economic growth and stability. When the domestic public debt growth increases, the capital markets develop. However, when the debt goes beyond the sustainable amounts, it results on a negative effect on the government. Because of the increased interest rates, the investors are highly discouraged.

The effects of domestic debt borrowing have been a major issue in South America Countries. Since 2008, the detail of South America Countries debt burden is quite disheartening. As of August 2008, the public debt was at USD. 867 billion according to Kobey (2016). This debt has continued to increase at a high rate that is quite alarming. According to a study that was conducted by Nord, Harris and Giugale (2013), the increase of the South America Countries external debt is largely eroding the country's sovereign rating. Because of the limited studies on the effects of domestic debt on capital market development, getting research papers done by other scholars was a bit of a challenge. Thus, this created a research problem where the impacts of domestic debt need to be understood. What are the effects of domestic debt on capital market development on South America Countries?

\subsection{Research Objective}

The core objective of this study was to examine the impacts of domestic public debt on the capital market development in South America Countries.

\subsection{Theoretical Review}

\subsubsection{Keynesian Model}

In his attempts to understand the great depression, John Keynes developed the Keynesian model back in 1930s. According to Keynes, the increase of the public debt through multiple effects ends up raising the National income. Keynes linked public borrowing with deficit financing that authorizes the government to borrow for all purposes that result to an increased demand in the economy that ends up increasing employment and output. This model is a macroeconomic model in that it follows the Keynesian economic principles (King, 1993).

The Keynesian model has three macroeconomic sectors that include the two sectors, three sectors and four sectors. This model has in the past been used to analyze various factors that include 
business cycles, monetary and fiscal policies. According to this model, public debt does not have a direct burden to the economic growth. However, an effect comes when expenditure is experienced. When it comes to the internal debt, this is the debt that the government owes to itself and may not contribute anything to the country's resources. On the other hand, external debt adds resources to the country as Mingo, Junkunc and Morales (2018) notes. This model also explains what happens when a government enters a capital market to borrow. When the government goes to the banks to borrow, the banks have surplus since businesses that are regular customers are in most cases reluctant to borrow. Because of the businesses' increased capacity, they cannot borrow to create more. Lack of the private sector loan demand increases the bank's willingness to lend more finances to the government at a low interest. Through this model, one gets to understand the government's spending and the effects it has on outputs and inflation.

\subsubsection{David Ricardo Theory}

In this theory, Ricardo and Churchman (2001) argue that the society's burden from the government spending is as a result of the wastage use of the expenditure. According to this theory, there are many allocative effects of tax burden on the economy that comes from public borrowings. In this theory, Ricardo said that the government's wastage use of the debts borrowed affects its citizen as according to the Ricardian equivalence theorem. In this case, it doesn't matter where the government gets its money either through debts or taxation but what matters is its usage.

When a country uses public debt to finance its projects, citizens tend to pay less money but future generation will have to pay more (Contessi, 2012). Through this theory, the study will examine the effects of government's public debt misappropriation and its effects on the future generations.

\subsubsection{The Debt Overhang Theory}

The debt overhang theory by Krugman explains the sustainability of the external debts. According to Barro and Grilli (1994), who is the theory's author, debt overhang is a presence of an existing inherited debt where creditors lack confidence with the borrower. According to this theory, a likelihood of the country's inability to pay debt discourages further domestic and foreign investment. As Adofu and Abula (2010) notes in their work, a heavy debt burden impedes the economic growth especially in developing countries. Also, high debts tend to highly undermine the macroeconomic stability since budget deficits are increased. When a country is not in a position to pay its debts, the debtor country don't invest and the country is unable to meet debt obligations unless they take new loans as well as debt relief. Another way debt overhang affects the economic growth is the fact that large debt stock increase expectations that debt service will be financed through distortionary measures. As Adofu and Abula (2010), the future taxes uncertainty for private domestic agent affects the domestic economy.

In various countries where the indebtedness is heavy, debt overhang becomes the main cause of a slow economic growth. According to this theory, a slow economic growth can be explained by noting that a country that is serving debts may use all of its resources on that. In this case, the potential of gaining returns from the government's activities are challenged. As Cunningham (1993) argues in his work, debt overhang is not as a result of debt accumulation but rather difficulties a country faces when it comes to debt elimination. Debt overhang reduces a country's macroeconomic performance. 


\subsection{Empirical Review}

According to a study by Akram (2010), issues that surround the effects of accumulation of domestic debt in a country have been a controversial issue for many years. Because of many international debts, the country is seeking other ways of financing their projects that negatively affects the country's capital market development. In an attempt to improve the welfare of South America Countries, the government has engaged in public borrowing since the domestic savings cannot cater for all the expenditure. In 2013, the public debt was around $39.8 \%$ of the GDP. This has continued to increase and in 2014, the debt went to $44.2 \%$ and $52.8 \%$ in 2015 . The increase of this debt continued increasing after the issuance of the $\$ 2.75$ billion that was offered in December 2015. This debt has been placed in infrastructural projects that include SGR among many others. From this analysis, it is evident that the public debt is growing and it may go to uncontrollable heights in future and if not effectively managed, the country's economic development will be largely affected.

Karazijienè and Sabonienè (2009) argued that public borrowing is inevitable especially when it comes to developing economies. According to their studies, public borrowing especially in developing countries is inevitable and not a reprehensible phenomenon of economic growth. Domestic debt offers a country an opportunity to substitute delay of repayment with better rates (Ribeiro, Vaicekauskas and Lakstutiene, 2012). Despite the fact that Ribeiro, Vaicekauskas and Lakstutiene (2012) considers domestic debt as a safer option compared to external debt, they also argue that domestic debt can also wear country's economic growth. In their work, Emram and Farazi (2009) examined the negative effects of domestic debt to a developing country. According to their study, domestic debt may derail a country's economic growth. The study by Adofu and Abula (2010) also supports the idea that domestic debt affects an economy negatively. In their study that was conducted between 1986 and 2005, it was found that domestic debt negatively affected Nigeria's economic growth.

Domestic debt largely affects a country's capital market development. In their work, Bildirici and Ersion (2007) argue that inflation rates are affected by domestic debt. This study examined countries that had high inflation rates and according to this study, domestic debt increases a country's inflation. When the countries experienced an increasing debt to GDP ratio, the countries had to borrow at a higher cost. The study concluded by saying that the increased cost of borrowing is as a result of the non-Ricardian fiscal policies.

According to a study that was conducted by Carlin and Mayer (2003), country's financial system structures have a strong relationship with economic growth. Another study that linked economic growth and financial market development is the study by Garretsen, Lensink and Sterken (2004). In this study, the authors argued that $1 \%$ of economic growth improvement determines up to $0.4 \%$ rise in the market capitalization. In their work, Beck, Lundberg and Majnoni (2006), found that there is a positive correlation between capital market development and economic growth.

\subsection{Research Methodology}

The study used a descriptive research, which involved the measurement, classification, analysis, This study adopted the descriptive study design. This study used 14 South America Countries capital markets as its population. The countries that include Argentina, Bolivia, Brazil, Chile, Colombia, Ecuador, Falkland Islands (United Kingdom), French Guiana (France), Guyana, Paraguay, Peru, Suriname, Uruguay and Venezuela were chosen as the population since they have similar regulations in relation to domestic public debt. Due to the small population, no sampling 
was conducted. This data was obtained from various sources that include South America Countries Central Banks, World Bank information, National Treasury Public Debt Department.

\subsection{Results and Discussions}

\subsubsection{Descriptive Statistics}

Table 1 gives descriptive findings including mean, standard deviation, minimum values as well as maximum values for total debt value, inflation rate interest rates and gross capital formation for the South America Countries. The period under study was 10 years from 2008 to 2017.

Table 1: Descriptive Statistics

\begin{tabular}{lccccccc}
\hline & $\mathbf{N}$ & $\begin{array}{c}\text { Minimu } \\
\mathbf{m}\end{array}$ & Maximum & Mean & $\begin{array}{c}\text { Std. } \\
\text { Deviation }\end{array}$ & Skewness & Kurtosis \\
\hline $\begin{array}{l}\text { Gross Capital } \\
\text { Formation }\end{array}$ & 50 & 16.8917 & 33.2404 & 25.18152 & 3.7080602 & 0.23 & 2.98 \\
$\begin{array}{l}\text { Domestic } \\
\text { Public Debt }\end{array}$ & 50 & 152 & 14368 & 3551.89 & 3453.63 & 0.2 & 2.7 \\
$\begin{array}{l}\text { Inflation } \\
\text { Interest Rate }\end{array}$ & 50 & 1.8 & 26.2 & 8.683 & 5.2418 & 0.54 & 2.77 \\
\hline
\end{tabular}

The findings show that the minimum value for gross capital formulation was $16.89 \%$ with a maximum of $33.24 \%$. The mean value was $25.18 \%$ with a standard deviation of 3.7 with a Skewness and Kurtosis value of 0.23 and 2.98 respectively. The minimum value for domestic public debt ('000 000 USD) was 152 with a maximum of 14,368. The mean value for domestic public debt was 3,453.63 with a standard deviation of 3,453.63 with a Skewness and Kurtosis value of 0.2 and 2.7 respectively. Inflation rate had a minimum of $1.8 \%$ and a maximum of $26.2 \%$. The mean value was $8.683 \%$ with a standard deviation of $5.24 \%$ with a Skewness and Kurtosis value of 0.54 and 2.77 respectively. Lastly, interest rate had a minimum of $4.103 \%$ with a maximum of $16.23 \%$. The mean value for interest rate was $8.64 \%$ with a standard deviation of $2.52 \%$ with a Skewness and Kurtosis value of 0.69 and 3.06 respectively.

\subsection{Correlation Analysis}

The study conducted correlation analysis for the variables that are domestic public debt, inflation rates and interest rates on capital markets development in order to examine the nature of the statistical relationships between each pair of variables. Table 3 shows the correlation matrix of all the variables.

Table 3: Correlation Matrix

\begin{tabular}{|c|c|c|c|c|c|}
\hline Variable & & $\begin{array}{l}\text { Gross Capital } \\
\text { Formation }\end{array}$ & $\begin{array}{c}\text { Debt in } \\
\text { USD }\end{array}$ & Inflation & Interest Rate \\
\hline Gross Capital & Pearson & & & & \\
\hline Formation & $\begin{array}{l}\text { Correlation } \\
\text { Sig. (2-tailed) }\end{array}$ & 1.000 & & & \\
\hline Domestic Public & Pearson & & & & \\
\hline Debt & $\begin{array}{l}\text { Correlation } \\
\text { Sig. (2-tailed) }\end{array}$ & $\begin{array}{l}.746^{* *} \\
0.000\end{array}$ & 1.000 & & \\
\hline
\end{tabular}




\begin{tabular}{|c|c|c|c|c|c|}
\hline \multirow{3}{*}{ Inflation } & Pearson & & & \multirow{3}{*}{1.000} & \multirow{6}{*}{1.000} \\
\hline & Correlation & $-.526 * *$ & $.568 * *$ & & \\
\hline & Sig. (2-tailed) & 0.000 & 0.000 & & \\
\hline \multirow{3}{*}{ Interest Rate } & Pearson & & & & \\
\hline & Correlation & $.494 * *$ & $-.327 *$ & -0.137 & \\
\hline & Sig. (2-tailed) & 0.000 & 0.021 & 0.342 & \\
\hline
\end{tabular}

The results in Table 3 show that domestic public debt $(0.746,0.000)$ had a positive and significant relationship with gross capital formation while inflation $(-0.526,0.000)$ had a negative and significant relationship with gross capital formation. Interest rate $(0.494,0.000)$ revealed a positive and significant relationship with gross capital formation.

\subsection{Regression Analysis}

Regression analysis was conducted in order to examine the coefficient of determination, the statistical significance of the model used and the regression model. The results of the regression analysis are presented in the following tables.

The results presented in Table 4 present the fitness of model used of the regression model in explaining the study phenomena. Domestic public debt, inflation and interest rate were found to be satisfactory variables in explaining capital markets development. This was supported by coefficient of determination also known as the R square of $64.6 \%$. This means that domestic public debt, inflation and interest rate explain $64.6 \%$ of the variations in the dependent variable, which is capital markets development.

This results further means that the model applied to link the relationship of the variables was satisfactory.

Table 4: Model Fitness

\begin{tabular}{lcccc}
\hline Model & R & R Square & Adjusted R Square & Std. Error of the Estimate \\
\hline 1 & $.804 \mathrm{a}$ & 0.646 & 0.623 & 2.2769971 \\
\hline
\end{tabular}

In statistics, significance testing the p-value indicates the level of relation of the independent variable to the dependent variable. If the significance number found were less than the critical value also known as the probability value (p) which is statistically set at 0.05 , then the conclusion would be that the model is significant in explaining the relationship; else, the model would be regarded as non-significant( Kothari, 2004)

Table 5 gives the outcomes on the analysis of variance (ANOVA). The outcomes show that the general model was statistically significant. Further, the outcomes suggest that the independent variables are good indicators of capital markets development. This was supported by an F statistic of 27.982 and the reported p value (0.000) which was less than the conventional probability of 0.05 significance level. 
Table 5: Analysis of Variance (ANOVA)

\begin{tabular}{|c|c|c|c|c|c|c|}
\hline Model & & Sum of Squares & df & Mean Square & $\mathbf{F}$ & Sig. \\
\hline & Regression & 435.239 & 3 & 145.08 & 27.982 & $.000 \mathrm{~b}$ \\
\hline & Residual & 238.497 & 46 & 5.185 & & \\
\hline & Total & 673.736 & 49 & & & \\
\hline
\end{tabular}

a Dependent Variable: Gross Capital Formation

b Predictors: (Constant), Interest Rate, Inflation, Domestic Public Debt

Regression of coefficients results in Table 6 shows that domestic public debt and capital markets development are positive and significant related $(\mathrm{r}=4.518, \mathrm{p}=0.030)$. The results further indicated that inflation and capital markets development are negatively and insignificantly related $(\mathrm{r}=-0.093$, $\mathrm{p}=0.116$ ). It was further established that interest rate and capital markets development were positively and significantly related $(\mathrm{r}=0.345, \mathrm{p}=0.003)$. This implies that an increase in domestic public debt $(\mathrm{r}=4.518, \mathrm{p}=0.030)$ and interest rate $(\mathrm{r}=0.345, \mathrm{p}=0.003)$ led to an improvement in capital markets development. However an increase in inflation $(r=0.093, p=0.116)$ led to a reduction in in capital markets development as shown in Table 6.

Table 6: Regression of Coefficients

\begin{tabular}{lccccc}
\hline & \multicolumn{2}{c}{ Unstandardized Coefficients } & \multicolumn{3}{c}{ Standardized Coefficients } \\
& B & Std. Error & Beta & t & Sig. \\
\hline (Constant) & 41.718 & 3.721 & & 11.211 & 0.000 \\
Domestic Public Debt & 4.518 & 0.913 & 0.554 & 4.947 & 0.000 \\
Inflation & -0.093 & 0.058 & -0.171 & -1.601 & 0.116 \\
Interest Rate & 0.345 & 0.111 & 0.290 & 3.114 & 0.003 \\
a Dependent Variable: Gross Capital Formation & & & & \\
\hline
\end{tabular}

The multiple regression model was laid as below.

$\mathrm{Y}=41.718+4.518 \mathrm{X}_{1}-0.093 \mathrm{X}_{2}+0.345 \mathrm{X}_{3}$

\subsection{Interpretation of the Findings}

A fitness of model was used in the regression model in explaining the study phenomena. Domestic public debt, inflation and interest rate were found to be satisfactory variables in explaining capital markets development. This was supported by coefficient of determination also known as the $\mathrm{R}$ square of $64.6 \%$. The skewness and Kurtosis in the descriptive analysis confirmed that the data was normally distributed. Correlation results revealed that domestic public debt had a positive and significance relationship with gross capital formation. Further, regression of coefficients results revealed that domestic public debt and capital markets development are positive and significant related. Domestic debt should be encouraged since it has a positive effect on financial market development in all the South America Countries this will promote stability and financial independence in the economy, inflation should be well managed since it's increase could harm the 
development of financial markets this can clearly be seen in the correlation coefficients where inflation rates have a negative relationship with financial markets development this means that the higher the rate of inflation the lower the rate of financial development. The findings of the study support the Keynesian model.

The findings are consistent with Putunoi and Mutuku (2013) who argues that domestic debt affects a country's economic growth. In a study that was conducted between 2000-2010 using the EngleGranger (1987) residual based and Johansen (1988) VAR based co-integration tests; it was revealed that domestic debt largely supports a country's economic growth. Domestic debt expansion has significant effects on a country's economic growth (Putunoi \& Mutuku, 2013). The findings also agree with Karazijiene and Saboniene (2009) who argued that public borrowing is inevitable especially when it comes to developing economies. According to their studies, public borrowing especially in developing countries is inevitable and not a reprehensible phenomenon of economic growth. Domestic debt offers a country an opportunity to substitute delay of repayment with better rates (Ribeiro, Vaicekauskas and Lakstutiene, 2012). Despite the fact that Ribeiro, Vaicekauskas and Lakstutiene (2012) considers domestic debt as a safer option compared to external debt, they also argue that domestic debt can also wear country's economic growth.

Correlation results revealed that inflation $(-0.526,0.000)$ had a negative and significant relationship with gross capital formation. Regression results further indicated that inflation and capital markets development are negatively and insignificantly related $(\mathrm{r}=-0.093, \mathrm{p}=0.116)$. This implies that an increase in inflation rates leads to a unitary reduction in capital markets development by 0.093 units other factors held constant. These results are in agreement with Ersion (2007) who examined countries that had high inflation rates and according to this study, domestic debt increases a country's inflation and thus lowers capital markets development.

Lastly, correlation results revealed that interest rate $(0.494,0.000)$ had a positive and significance relationship with gross capital formation. Regression results showed that interest rate and capital markets development were positively and significantly related $(\mathrm{r}=0.345, \mathrm{p}=0.003)$. This implies that an increase interest rates leads to a unitary improvement in capital markets development by 0.345 units other factors held constant.

\subsection{Conclusions}

The study concluded that there is a positive relationship between high domestic public debt and capital market development, an increase in domestic debt causes the capital market development to decrease. When a country borrows more domestic debt and less external debt it promotes capital markets development in the long run. The regression model used in the study was statistically significant in explaining the effect of domestic public debt on capital markets development in South America Countries. The study further concluded that inflation rate has a negative impact on financial market development this implies that inflation had a negative impact on capital markets development. It also conclude that an increase in interest rate impact positively the capital markets development.

Domestic debt expansion had a positive significant effect on South America Countries capital markets growth. The relationship between capital markets growth and domestic debt is evidenced by the fact that domestic debt markets promote financial depth and economic efficiency. This is as a result of increased expansion of capital market and financial sector liberalization in the South America Countries recently which drives capital markets development. 


\subsection{Recommendations}

Based on these findings, the study recommends on continued deepening of the capital markets to lengthen further the maturity profile of domestic debt and diversification of the investor base. The study further recommends on continued implementation of policies to support macroeconomic stability and faster economic growth. This includes restructuring public debt towards external borrowing which is comparably cheaper than domestic debt, and rationalization of recurrent expenditures to contain the widening deficit in the primary balance would be necessary in the medium-term to ensure that public debt remains on a sustainable path to allow for capital markets development. A notable advantage of restructuring public debt towards external borrowing through issuance of sovereign bonds is that it will help to benchmark South America Countries in credit and facilitate access to international capital markets by corporate entities in the country thereby stepping up investment activities.

To ensure the success of the domestic borrowing programme, the government should continue to implement measures to maintain confidence in the capital markets through prudent fiscal policy and adherence to the annual domestic borrowing calendar. The government should also develop a framework for capturing and monitoring non-residents investment in government securities for purposes of improving the monitoring of foreign direct investment in the country.

The governments of the South America Countries should promote moderate levels of domestic borrowing which can be sustained by the respective countries as it promotes economic growth if used in productive and efficient avenues. However, domestic debt is usually expensive and should be minimized since it has wider negative macroeconomic effects for instance, if interest rate on treasury bills rise, banks target treasury bills and not lending to borrowers, interest rates and inflation also goes up. The governments can privatize some of the public assets in order to cut large public expenditure and raise revenue on a temporary basis. Corruption and leakages in public funds should be reduced to ensure that government expenditure promotes capital markets development and growth.

\section{References}

Abbas, A. S. M. and Christensen, J. E. (2017). The Role of Domestic Markets in Economic Growth: An Empirical Investigation for Low-income Countries and Emerging Markets". IMF.

Adofu, I. and Abula, M. (2019). Domestic Debt and the Nigerian Economy”. Current Research Journal of Economic Theory, Vol. 2(1), pp 22-26.

Akram, N. (2018). Impact of Public Debt on Economic Growth in Pakistan. The Pakistan Development Review, 50(4), 599-615. https://doi.org/10.30541/v50i4IIpp.599-615

Alemayehu, Geda. (2012): Debt issues in South America Countries: Thinking beyond the HIPC initiative to solving structural problems”. WIDER Discussion Paper, no. WDP 2002/35. Helsinki: UN WIDER.

AMO, M.A. (2010).Understanding the Growth of Latin Financial Market. IMF Working Paper. Avendano, R., Melguizo, A., \& Miner, S. (2017). Chinese FDI in Latin America: new trends with global implications. Washington: Atlantic Council. 
Bildirici, M., \& Ersin, O. O. (2017). Domestic debt, inflation and economic crises: A panel cointegration application to emerging and developed economies. Applied Econometrics and International Development, 7(1), 31-47.

Brauninger, M. (2013). Public Debt and Endogenous Growth. Physica-Verlag Heidelberg, New York.

Carlin, W. Mayer, C. (2013). Finance, Investment, and Growth, Journal of Financial Economics, 69, pp. 191-226. https://doi.org/10.1016/S0304-405X(03)00112-0

Contessi, S. (2012). An Application of Conventional Sovereign Debt Sustainability Analysis to the Current Debt Crises. Federal Reserve Bank of St. Louis Review, 94(3), 197-220. https://doi.org/10.20955/r.94.197-220

Coşkun, Y., Seven, Ü, Ertuğrul, H. M., \& Ulussever, T. (2017). Capital market and economic growth nexus: Evidence from Turkey. Central Bank Review, 17(1), 19-29. https://doi.org/10.1016/j.cbrev.2017.02.003

Cunningham, R. T. (2013). The Effects of Debt Burden on Economic Growth in Heavily Indebted Developing Countries. Journal of Economic Development, 18(1), 115-126.

Garretsen, H.; Lensink, R. Sterken, E. (2014). Growth, financial development, societal norms and legal institutions, Journal of International Financial Markets, Institutions and Money, 14, pp.165-183. https://doi.org/10.1016/j.intfin.2003.06.002

Meensel, N.M. (2018). Impact of Public Debt. Economic Freedom and Growth.

Mingo, S., Junkunc, M., \& Morales, F. (2018). The interplay between home and host country institutions in an emerging market context: Private equity in Latin America. Journal of World Business, 53(5), 653-667. https://doi.org/10.1016/j.jwb.2018.03.005 